Martin D. Henry (ITQ, vol. 71/3\&4, 2006, 348-49)

\title{
Is Christianity Life-Affirming?
}

'What does it profit a man to gain the whole world, and lose his own soul?', Jesus asks in the Gospels (Mk 8. 36). 'Here we have no abiding city,' we read in the Letter to the Hebrews (Heb 13. 14). 'I want no more of what men call life,' wrote Ignatius of Antioch, one of early Christianity's most reputable witnesses, literally, in his Epistle to the Romans (§8). The Middle Ages, for their part, are saturated with works on the theme of contempt for, or flight from, the world. Indeed the very notion of 'worldliness' is suspect in traditionally Christian cultures. And, last but not least, the idea of renouncing worldly joys, of abandoning house and home or the possibility of founding a family of one's own 'for the sake of the kingdom of heaven' (cf. Mt 19. 12, 29), has in the course of Christian history been seen as not merely compatible with, but as the most authentic expression of, Christian faith.

Faced with such a battery of evidence about the nature of Christianity, evidence that could be extended almost ad infinitum, those who would maintain the contrary would appear to have the burden of proof on their shoulders. Yet the contrary is now in fact being asserted, and from the highest positions in the Catholic world. Christianity, we are now assured, is life-affirming. Does this apparent volte-face on the part of church leaders represent a radically new interpretation of the Christian faith? Or does it signify that what for so long seemed to be a world-denying, resolutely ascetical faith is, when really understood, not world-denying at all? The answers to these questions are not immediately obvious. But what does seem to be beyond doubt is that criticisms of Christianity made since the Enlightenment - which was itself, of course, no friend of asceticism - are beginning to bear fruit.

Moved, even stung, by the critique of a world-denying, flesh-tormenting religion mounted by thinkers like Feuerbach and, especially, Nietzsche, or by men of 
letters such as Rilke, Christian leaders have been reassessing how they should present Christianity to an increasingly sceptical world. In this task, they undoubtedly have strong cards to play, which they don't even have to go outside the Christian tradition to seek. Rather, all that is needed to endorse the life-affirming nature of Christianity lies deeply embedded within the Christian tradition itself. First and foremost, perhaps, there is Christianity's own doctrine of creation (taken over from Judaism), which speaks of God finding his work of creation 'good,' not, as the Gnostics were to claim, a catastrophe or a 'fall.' And the sacramental, anti-iconoclastic dimension of Catholic Christianity hardly needs to be laboured. Hence the view of a Catholic sceptic, George Santayana, may be closer to the truth of Christianity than any pessimistic account of its meaning. In Soliloquies in England and Later Soliloquies, Santayana wrote: 'Christ loved the world, in an erotic sense in which Buddha did not love it: and the world has loved the cross as it can never love the Bo-tree. ${ }^{1}$ That, of course, still leaves unanswered the question of how Christianity came to be associated with a grim view of life to begin with.

George Santayana, Soliloquies in England and Later Soliloquies (London: Constable \& Company Ltd: 1922), 94. 